\title{
Poverty and Coping strategies of Unemployed Youths in Cross River State, Nigeria
}

\author{
EMMANUEL NWAKANMA* and JOSEPH EGIDI IGBE
}

Department of Sociology, University of Port Harcourt, Rivers State, Nigeria.

\section{Abstract}

The study investigates how unemployed youths in Cross River state respond to and cope with poor economic conditions. The phenomenon of poverty has been identified as one of the increasing social challenges in Nigeria and has been linked to a number of social problems including street crime, substance abuse, internet fraud, armed robbery, ritual killings, kidnapping, and youth restiveness. Scholars have also argued that whereas the youth is the locomotive of national development and contribute immensely to the sustenance of the developmental momentum of a nation; youths in Nigeria are largely unemployed and redundant. The social consequences of this are enormous and can only be explained from the lens of the restricted opportunity theory and the strain theory. The study employed a cross-sectional survey research design involving questionnaires, interviews, descriptive statistics and 1,010 purposively selected respondents from six local government areas in the three senatorial districts of Cross River. The findings of the study revealed that youth poverty is a growing concern in Cross River state, and is caused by limited access to loans, lack of job opportunities, policy paralysis, among many other factors. Respondents of the study further noted that unemployed youths in the state cope with the hardship associated with poverty and unemployment by engaging in various activities including negative ones such as commercial sex work, theft, cyber fraud, and armed robbery. It is thus recommended, among other things, that the Nigerian State must invest in youth development by creating programmes and funding for small scale businesses, vocational training, and skills development.

\section{Introduction}

The phenomenon of increasing poverty levels has remained a major concern in most developing countries in Sub-Saharan Africa, especially in Nigeria where the problem of poverty affects a large part of its population and contributes to the

CONTACT Emmanuel Nwakanma $\$ emmanuel.nwakanma@uniport.edu.ng 9 Department Of Sociology, University Of Port Harcourt, Rivers State, Nigeria.

\section{(c) (i)}

(C) 2020 The Author(s). Published by Enviro Research Publishers.

This is an 2 Open Access article licensed under a Creative Commons license: Attribution 4.0 International (CC-BY).

Doi: http://dx.doi.org/10.12944/CRJSSH.3.2.13 
proliferation of social problems such as street crime, substance abuse, internet fraud, armed robbery, ritual killings, kidnapping, as well as many other social and public health concerns. As noted by a recent World Bank Poverty and Shared Prosperity report of 2017, Sub-Saharan Africa is the only region in the world where the total number of extremely poor people consistently rises rather than decreases and affecting over $41 \%$ of her total population. ${ }^{1,2}$ While the rate of extremely poor persons, (defined as persons earning less than $\$ 1.90$ or $€ 1.64$ a day) has dramatically declined globally and falling from 1.9 billion in 1990 to approximately 736 million persons today, an estimated 413 million people currently live in severe poverty in Africa. This number, as noted by Müller-Jung, ${ }^{1}$ is more than half of the world's total poverty rate. Scholars such as Kazeem, ${ }^{3}$ Akanle and Adésìnà, ${ }^{4}$ Anyanwu ${ }^{5}$ and Anyanwu and Shepherd, Mitchell, Lewis, Lenhardt, Jones, Scott, and Muir-Wood, ${ }^{6}$ have all noted that the situation of poverty remains a major bane to Africa's sustainable development and affects its reputation in the comity of nations. Nigeria, despite being among the oil richest countries in the world, besides her vast wealth in many other mineral and human resources, is still grappling with the problem of poverty with over 86.9 million of its citizens currently living in poverty. ${ }^{3}$ More mysterious and unexplainable is the fact that poverty in Nigeria is chronic, unrelenting, and rising regardless of the various methods employed by succeeding governments to tackle it.

Whereas a number of factors, such as poor access to education, lack of economic infrastructure, unfair distribution of material resources, marginalization, the inability to negotiate loans and invest, among many others, have been identified as root causes of the rising poverty in Nigeria, the phenomenon of unemployment remains significant. As shown in records available to the National Bureau of Statistics, while the population of economically active persons, that is those between $15-64$ years of age, increased from 111.1 million in Q3 2017 to 115.5 million in Q3 2018, the total number of people classified as unemployed in Nigeria increased from 17.6 million in Q4 2017 to 20.9 million in Q3 of 2018. Currently, the unemployment rate has from $23.1 \%$ in 2019 to risen to $33.5 \%$ in the early quarters of 2020 . This is alongside a rising national poverty rate which stands at $40.09 \%$ or 82.9 million persons. ${ }^{7,8,9}$ Unemployment is understood to occur when a proportion of the labour force that is able and available for work do not work as a result of the unavailability of profitable jobs to engage themselves even for a period of time. In simpler terms, an unemployed person is one who has no gainful employment, no means of income and as a result, cannot fulfil basic needs and responsibilities. Whereas it is practically possible for an individual to be employed and remain poor, unemployment further emasculates people financially and makes it difficult for them to make a decent living. For this reason, unemployment in Nigeria has remained a major concern for the State, private agencies, non-governmental organisations, and scholars across the country. For instance, in Cross River State alone, the unemployment rate is calculated to be $30.6 \%$ in 2019 , as many persons within the productive age are not able to access gainful employment irrespective of their qualification and skillsets. ${ }^{10,7}$

Unemployment statistics in Nigeria have been associated with several problems and have remained a major concern for policymakers, nongovernmental agencies as well as scholars in the field of development sociology, criminology, and social psychology. The notion of unemployment accentuates the redundancy and associated challenges faced by persons who are available for productive employment but are unable to work owing to the unavailability of jobs or gainful employment. This concern amplifies in the face of a teeming population of youths and the expansive nature of Nigeria's population as shown in the country's population pyramid (see Figure 1). While Nigeria's youth bulge may have been an advantage particularly as in the world all over, the youth is considered the locomotive of national development mainly because the youth sustain the developmental momentum of a nation; however, regrettably, the reverse has been the case in Nigeria. Youth in Nigeria has been characterized by restiveness, substance abuse, violence, laziness, and criminality. Furthermore, a cursory look at our society today will reveal that the poverty situation is steadily increasing and is affecting the youth population the most. This may not also be unconnected to the rising cases of crime, emigration, violence, and restiveness in the country and the difficulty of many Nigerian youths to contribute significantly to national development and 
in the deepening and consolidation of democracy in the country. In a sense, therefore, it can be argued that the high incidence of youth unemployment and poverty in Nigeria creates the very basis of Nigeria's under development.

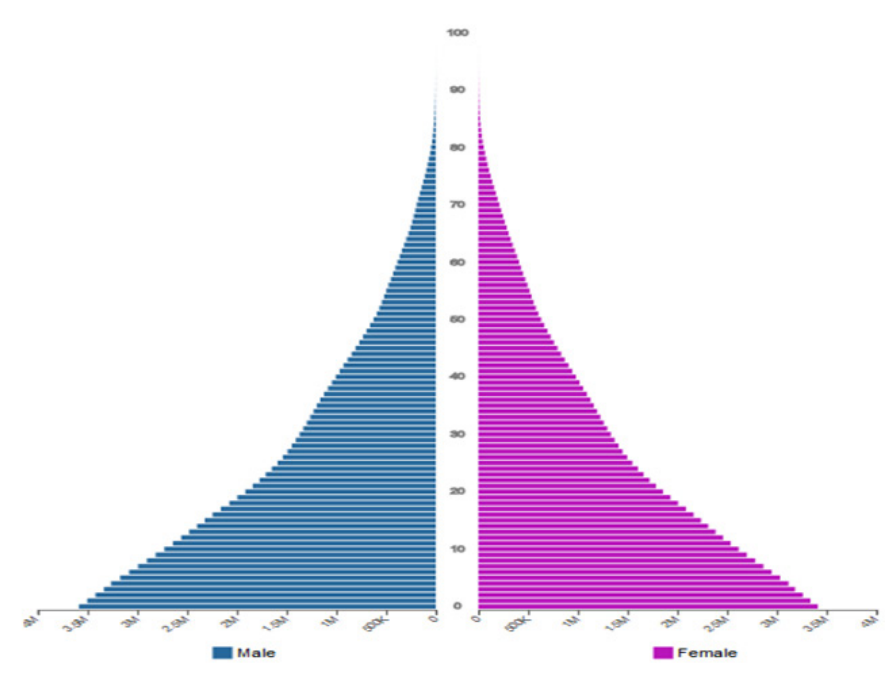

Fig. 1: Nigeria's Population pyramid. Source: World Population Review

Although several studies have investigated the nature, causes, and dimensions of poverty and unemployment in Cross River State; however, none of them have empirically investigated the coping strategies of unemployed youths in the face of increasing poverty in Cross River state. For instance, Ingwe ${ }^{12}$ examined the phenomenon of persisting poverty, unemployment, and underemployment in Cross River State; but the study only employed a theoretical approach to explaining the need for the State to improve good governance and increase participation in the State Economic Empowerment and Development Strategy (SEEDS) as a way to ameliorate the situation. Essia and Yusuf ${ }^{13}$ have also looked at definitions of the 'active poor' and the challenge of youth unemployment in Cross River State, while Inyang, Arikpo, and Ndiyo, ${ }^{14}$ in a later study, examined the phenomenon of unemployment and poverty in Cross River State, however relying on data from secondary sources. The only recent literature that comes close to an empirical study of the phenomenon of unemployment in Cross River State is the study by Okpa:15 however, the study focused on unemployment and implications for selected drug trafficking suspects in the custody of the Cross River State Command of National Drug Law Enforcement Agency (NDLEA). It is thus the aim of this paper to empirically investigate the phenomenon of poverty and the coping strategies of unemployed youths in Cross River State. In pursuance of this aim, the study set out to accomplish the following objectives: investigate the nature and causes of poverty among youths in Cross River State; examine the extent of the impact of poverty on unemployed youths in Cross River State, investigate how unemployed youths in Cross River State respond to and cope with poverty, and also suggest possible ameliorative strategies for youth poverty and unemployment in Cross River State.

\section{Review of Literature Conceptual Clarification}

The concept of unemployment and poverty are deeply intertwined and are understood to have intricate socio-economic, cultural, and political dimensions. The two concepts evoke different meanings and sentiments, including the notion that they are related to inability, lack, and deficiency. For instance, unemployment is considered as a major social problem that explains the inability of one to work, earn income, and meet basic life needs. A publication by the Organisation for Economic Cooperation and Development ${ }^{16}$ in 2019 suggests that unemployment is when persons within a specific productive age are not in any paid employment or self-employment but are currently available for 
work during a reference period. Fajana ${ }^{17}$ refers to unemployment as a condition in which it is difficult for individuals who are willing and able to work to find sufficient paying jobs. The National Bureau of Statistics defines an unemployed person as one who does not have work or only works for less than 20 hours a week. For NBS, ${ }^{7}$ the unemployed are those within the labour force, that is between 15 and 64 years of age, that are willing and able to work however are unable to find a paid job. For the International Statistical Standards, the term unemployment should in principle satisfy the three important criteria of being without work, being available for work, and seeking work. As a result, conventional explanations of unemployment do not include individuals such as students in full-time programmes, persons retired from active working life, children, and those not actively looking for a paying job. It also does not include individuals who work part-time, but want a full-time job. Real unemployment puts into consideration persons who are unable to find jobs, those who have severally searched for employment and are now exhausted, and those who would want to work but cannot due to ailments or schooling. ${ }^{18}$ Unemployment is used in this work to define persons who are willing, able and qualified to work but are currently unable to find any gainful employment, and as a result are jobless, engaged in low paying or low skill jobs, or in some petty business.

Youth unemployment is one of the macro-economic problems, which every responsible government is expected to regularly monitor and control. It has been adduced that the higher the unemployment rate in an economy, the higher the poverty levels and other associated social challenges. The rising rate of unemployment in Nigeria has been classified as a major bane to sustainable development in the country and has been linked to the increasing security risks and criminality in major parts of the country. The impact of unemployment in Nigeria is also evident in the eruptions of civil disobediences and agitations for cessation in parts of the country, such as the IPOB movement, recurring militancy in the Niger Delta region, Boko Haram terrorism, etc. Beyond these, NBS in 2017 has also stressed that youth unemployment in Nigeria contributes to the increasing misery index in the country, which has regrettably reached $49.5 \%$ as of $2017 .{ }^{19}$
The implication of this is that close to half of Nigeria's over 180 million people are, regrettably, miserable owing to various socio-economic, political and environmental challenges.

Poverty, on the other hand, indicates the lack of material means for proper existence as a member of society. It underscores the socio-economic status of persons who are unable to generate income or resources to adequately meet the basic needs of life. As the 1995 World Summit for Social Development ${ }^{20}$ clarified, "poverty is multidimensional and means a lack of income and productive resources sufficient to ensure sustainable livelihoods, hunger and malnutrition, ill-health, limited or lack of access to education and other basic services, increased morbidity and mortality, homelessness and inadequate housing, unsafe environments and social discrimination and exclusion, lack of participation and exclusion, and lack of participation in decision-making as well as in civil, social and cultural life". Furthermore, the United Nations, in 2006, opined that poverty is a situation in which individuals or groups do not have the requisite economic and social power to make a meaningful living in society. From the human rights perspective, poverty is not only a lack of economic or material resources but also a violation of human dignity. As noted in the Declaration and Programme of Action adopted at the International Conference on Human Rights in Vienna, in 1993, extreme poverty and social exclusion constitute a violation of human dignity particularly as it inhibits the full and effective enjoyment of human rights. The argument here, as articulated by the Center for Economic and Social rights, ${ }^{21}$ is that poverty erodes and nullifies the economic and social rights of persons including the right to good health and quality wellbeing, adequate housing, food, and safe water, and the right to education, all of which reduces one's ability to contribute to society.

Youth poverty is a serious global problem, which currently affects more than 500 million persons across the globe and has been associated with several problems. Currently, data available to Oxfam International ${ }^{22}$ reveals that $43 \%$ of the global youth labour force is either unemployed or trapped in working, while the poor are faced with excruciating situations of poor health, hunger, starvation, low 
levels of education, and reduced social mobility. As noted by Moore ${ }^{23}$ and Curtain, ${ }^{24}$ the challenge with youth poverty is not only because of the large numbers of youth that are currently living in absolute poverty across the globe and mostly in developing countries; it is further expanded by the fact that youths increasingly contend with issues of age-based discrimination and the uncertainties surrounding their transition to adulthood, particularly in the context of congested labour markets.

\section{Implications of Unemployment and Poverty}

Several studies, such as Glesson, ${ }^{25}$ Inyang, Arikpo, and Ndiyo14; Martinez, Ayala, and Ruiz-Huerta, ${ }^{26}$ have indicated that unemployment and poverty are both manifestations and precipitants of a plethora of social problems such as bad leadership, insecurity, policy paralysis, and governance volatility, etc, that are detrimental to human social existence locally and globally. Unemployment and Poverty, unfortunately, affects several youths and has serious implications for development in Nigeria. ${ }^{25,16,7}$ The extent of these statistics can only be understood in the face of the rising cases of emigration, kidnapping, internet fee fraud, armed robbery, and youth restiveness in Nigeria. In recent times, Nigeria has recorded so many cases of illegal migrants deported from other countries, as well as various cases of youth involvement in kidnapping, armed robbery, and internet fraud. Glesson ${ }^{25}$ has noted that the consequences for unemployment and poverty are multi-dimensional and both are grave and longlasting. For example, a 2009 Pennsylvania study found that unemployed workers died more than a year earlier than average. Furthermore, the longer unemployment lasts, the more extreme the health impacts on the unemployed are with increased depression and other health conditions worsening over time. In addition to the apparent loss of income, unemployed persons have also indicated the loss of close relationships and self-respect owing to their poverty situation. Again it has been noted that the longer unemployment lasts, the more it becomes more difficult for the affected individuals to find jobs again, mainly because employers become suspicious of the 'long-time unemployed' as it is known that an unemployed person would have lost most job skills over time.

As shown in Figure 2, Poverty and unemployment are also connected to an increase in crime and many other social vices. For instance, a National CaseControl Study of Serious Property Crimes, in 2016, published that unemployed persons are significantly more likely to commit vices such as gambling, prostitution, mugging, theft, kidnapping, and armed robbery. The study also found a correlation between youth joblessness and property crimes, such as burglary, carjacking, vandalism, and armed robbery. Scholars such as Kellog, ${ }^{27}$ Narayan and Petesch ${ }^{28}$ and Akire, ${ }^{29}$ have also noted that unemployment and poverty contribute to increased crime, exploitation of labour, and reduced economic development in a society. Studies by Alsan, Westerhaus, Herce, Nakashima and Farmer, ${ }^{30}$ Singh and Singh, ${ }^{31}$ and Goldsmith, Veum, and Darity ${ }^{32}$ have also revealed that globally, millions of persons suffer from serious 'diseases of poverty' which are diseases emanating

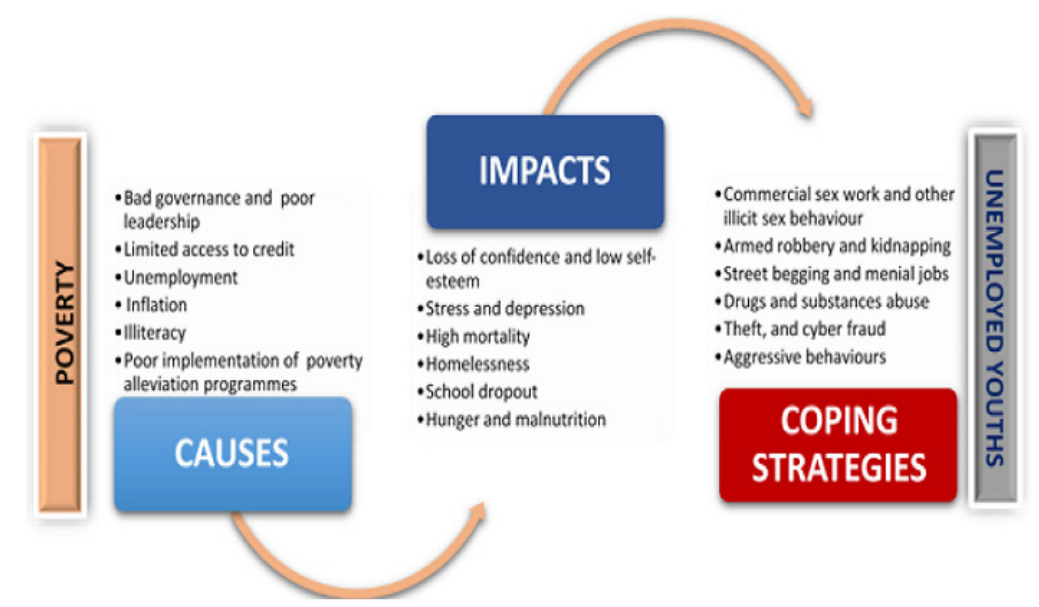

Fig. 2: Chart showing youth poverty and outcomes. Source: Authors' illustration 
from an inability to maintain safe health behaviours, and are more prevalent in low-income populations. They include infirmities such as malnutrition, starvation, and hunger, as well as spreads of infectious diseases, such as Lassa fever, HIV/AIDS, etc. Psychologenie ${ }^{33}$ and Heflin and Iceland ${ }^{34}$ have also pointed out that unemployment and poverty can also result in mental illness, depression and loss of self-esteem, increased anxiety, and feelings of inferiority, psychosis, and even suicide. This is because of the constant worry to find a job, the anxiety associated with the inability to meet personal needs, or that of loved ones can put stress on one's mental health.

\section{Theoretical Framework}

Different scholars, including Chakravarti, ${ }^{35}$ Grondona, ${ }^{36}$ Newman, ${ }^{37}$ and Lewis, ${ }^{38}$ have over the years proposed different theories as explanations for the pervasiveness of poverty and unemployment in society. Some of these theories attempt to distinguish between individual, systemic, geographic, and cultural sources of unemployment and poor economic circumstances. For example, Human capital theories argue that poverty and other undesirable economic circumstances are caused by poor individual choices, while the Economic geography theory attributes poor economic circumstances to poor infrastructure in certain geographic areas. It is, however, important to note that these theories, though different, altogether present an intellectual continuum in scholarly debates surrounding the phenomenon of poverty and unemployment in society. Among all of these, this paper adopts the 'Restricted opportunity theory' and the 'Strain theory' as explanations for the increasingly poor economic conditions of youths in Nigeria.

The restricted opportunity theory contends that the poor are socially disadvantaged persons who lack sufficient access to economic opportunities, including gainful employment, and as a result cannot avoid poverty unless their economic opportunities improve. Bradley Schiller, an economist, first introduced the restricted opportunity theory in his book 'The economics of poverty and discrimination' as one of the three theories of the causes of poverty. For Schiller, ${ }^{39}$ restricted opportunities explain the situation when individuals in a society do not have access to the same opportunities as everyone else based on social class, status, ethnic affiliation, sex, race, or religion. The restricted opportunity theory explains that poverty stems from situations that are usually beyond the control of a poor person. These circumstances, as noted by Crossman, ${ }^{40}$ Pineda, ${ }^{41}$ and Chakravarti, ${ }^{35}$ generally center on the absence of opportunities or the lack of access to such opportunities.

Central to this theory is the assumption that opportunities in the society are skewed and people who lack suitable and relatively abundant access to socio-economic opportunities, such as access to quality education, effective and efficient healthcare, safe communities, and relevant public services and programmes, cannot avoid poverty or will only be able to get out of their impoverished conditions unless their economic opportunities improve. A variant of this theory is the Differential Opportunity theory developed by American sociologists, Richard A. Cloward and Lloyd B. Ohlin, and presented in their book: Delinquency and opportunity: a theory of delinquent gangs, published in 1960. Cloward and Ohlin ${ }^{42}$ were of the opinion that the opportunity structures of the society vary for different people in the society; and while some are fortunate or use their vantage position to access social privileges, others contend with inadequate access to education, joblessness, and scarcity. The usual outcome is that this situation creates poverty for many in society. For instance, an unemployed person is most likely to have a financial crisis that reduces his or her overall purchasing capacity, capacity to meet needs, or stimulate social mobility.

The Strain theory on the other hand suggests that the failure to achieve positively valued goals by socially disadvantaged persons in the society generates strains or stressors that produce negative emotions and deviant behaviour. Robert Merton, Albert Cohen, Cloward and Ohlin, and Robert Agnew, who are the key proponents of the theory, all agree that whereas the society creates success goals and also prescribes approved means to achieve them; certain factors in the society can constrain some persons from accessing these means, thus causing an inability to achieve the conventional success goals. ${ }^{43,44}$ For instance, Robert Merton argued that deviance is one of the reactions to societal road blocks or limited opportunities 
people face in achieving socially accepted goals. ${ }^{44}$ Agnewm, ${ }^{45}$ in his general strain theory, equally argued that the inability to achieve culturally approved goals, negative experiences in the society, such as unemployment, homelessness, poverty, and discrimination, generates negative emotions which make for violent behaviour, deviance, or crime.

For Robert Agnew, three major strains, namely: the actual or anticipated failure to accomplish certain positively valued goals (e.g. wealth or education); the actual or expected elimination of positively valued stimuli (such as the painful death of an intimate friend); and the real or expected presentation of negative stimuli (such as child abuse), produces anger and frustration, creating pressure for deviant behaviour. ${ }^{43}$ Using these theories, one can explain how unemployment and poverty are socially created and possible negative outcomes.

\section{Methodology \\ Design and Study Area}

The Cross-sectional survey research design, which allows the use of qualitative and quantitative data in a short possible time, is adopted. This design is considered appropriate for this study because it provides a better and comprehensive understanding of the problem under study. The study area is Cross River State, Nigeria. Cross River is a coastal state located in the Niger Delta region with the state headquarters in the Metropolitan city of Calabar. The state has eighteen Local Government Areas which is further delineated into three senatorial (Southern, Central, and Northern Senatorial) Districts and with one hundred and ninety-three wards. ${ }^{46}$ Cross River State is considered appropriate for this study because of the dearth of reliable data on the phenomenon of poverty and the coping strategies of unemployed youths in Nigeria; hence, this work is posed to fill that gap with a view to creating awareness, influence policy, and expanding literature on the subject matter.

\section{Study Population and Procedures}

The target population of this study is the entire residents of Cross River State. The study population is limited to only youths in the three senatorial districts in Cross River State, Nigeria. The Nigerian National Youth Policy ${ }^{47}$ has defined youths as persons between 18 - 35 years of age; and within this range, the Nigerian National Population Commission and National Bureau of Statistics ${ }^{7}$ put the population of youths in Cross River State at 1,591,026. Using a Survey Monkey Sample Size Determinant, a sample size of 1,067 was obtained with a $95 \%$ confidence level and $3 \%$ margin of error for the overall youth population of $1,591,026$. With the help of a sample frame, simple random sampling was used to draw six (6) local government areas from the three senatorial districts of Cross River State, (i.e. 2 per district); while the purposive sampling technique was employed to select respondents from each of the selected LGA's. The inclusion criteria was that the respondents must be youths residing in the selected study area and were, at the time of the study, unemployed or underemployed (that is working in very low paying or low skill jobs, or in some petty business).

\section{Data Collection and Steps}

The mixed method of scientific investigation consisting of quantitative and qualitative approaches of data collection is adopted. The instruments for data collection were a self-completion structured questionnaire and an unstructured 'In-Depth Interview' (IDI). The research instruments were administered face-to-face by two researchers. Questionnaires help in the collection of a large amount of information from a large number of people in a short time possible and in a relatively cost-effective way. The study also observed all ethical principles guiding social researches of this nature including obtaining informed consent from respondents, getting permission for audio or video recording, ensuring voluntary participation, and the participant's right to withdraw when indicated. Ethical clearance was further obtained from all the local authorities in the study areas. The instruments were subjected to a pre-test and were further validated by two senior lecturers in the Department of Sociology, University of Calabar, Calabar. Out of the 1,067 questionnaires distributed, 1,010 copies were returned and used for analysis, while 57 copies were either missing or not properly completed and thus were rejected. This amounts to a $94.4 \%$ return rate, which is considered sufficient for use in data analysis.

Qualitative data were elicited using an unstructured in-depth interview guide. The IDI provides additional information far beyond the limits of the applied 
quantitative instrument, and thus was used to corroborate the findings of the quantitative data. The interview was conducted among fifteen (15) purposively selected participants from the sample from the selected communities. The selection of these participants was based on two criteria which supposes that the participants must be youths from the selected communities and must be deemed to know the subject matter. Again, participants were selected based on the principles of confidentiality of data, beneficence to participants, and voluntariness. Each respondent's interview lasted between 30 and 55 minutes.

Table 1: Sample break down of selected Local Government in the Senatorial Districts

\begin{tabular}{lccc}
\hline Senatorial District & Local Govt. selected & No Participants/District & Percentage \\
\hline \multirow{2}{*}{ Northern Senatorial District } & Obudu & 178 & 16.7 \\
& (Ogoja) & 178 & 16.7 \\
Central Senatorial District & Ikom & 178 & 16.7 \\
& (Ugep) & 178 & 16.7 \\
Southern Senatorial District & Akamkpa & 177 & 16.6 \\
& (Calabar South) & 178 & 16.7 \\
Total & & $\mathbf{1 , 0 6 7}$ & $\mathbf{1 0 0 . 0}$ \\
\hline
\end{tabular}

Source: Fieldwork, 2020

\section{Data Analysis and Results}

In analysing the data, a proper check is carried out on both the quantitative and qualitative components of the data collected to ensure that all items used for the analysis are properly responded to. Responses from the quantitative data were edited, coded, and analysed using appropriate descriptive statistics like frequency distribution tables, bar charts, and pie charts. Qualitative data are analysed using content analysis after proper editing and verbatim transcriptions were done by the researchers. Catchy phrases and expressions gathered were identified and organised under distinct themes.

The distribution of respondents by gender presented in Table 2 shows that $53.6 \%$ were males while the females constitute $46.4 \%$. The difference, however, not significant, indicates that males were more willing to participate in the survey than the females. This is because some female respondents were never comfortable to interact with unfamiliar faces. The information on the age category shows that $23.5 \%$ of the respondents were aged 18-23; however, the majority of the respondents sampled were between $24-29$ years and constituting $42.6 \%$. The remaining $33.8 \%$ of the respondents were aged $30-35$ years. The implication here is that the respondents who are 24-29 years were more available and willing to participate than other age brackets.

The presentation on the educational background of the respondents shows that $20.6 \%$ of the respondents had only First School Leaving Certificate (FSLC), followed by $31.9 \%$ of the respondents that had either Secondary School Certificate of Education (SSCE) or General Certificate of Education (GCE). Also, $26.1 \%$ had either a National Certificate of Education (NCE) or Ordinary National Diploma (OND), while, $19.5 \%$ had First Degrees in the form of Bachelor's Degree (BD) or Higher National Diploma (HND). In addition, $1.9 \%$ of the respondents are with either a Master's Degree (MD) or Doctorate (PH.D).

Appraising from this presentation, it shows overall that the majority of the respondents $(31.9 \%)$ had either SSCE or GCE. This provides an insight into the literacy level of the respondents. The final item on the table shows the respondent's employment status indicating that only $17.7 \%$ of the respondents are underemployed while the majority, $58.3 \%$, are fully unemployed; however, $24 \%$ of the respondents indicated that they operate some petty business. This finding implies that more than half of the 
NWAKANMA \& IGBE, Current Research Journal of Social Sciences, Vol. 03(2) 262-279 (2020) 270

respondents $(58.3 \%)$ have no gainful employment. Interestingly, this composition forms the basis of this study because it is in the interest of the researchers to know how the unemployed group is coping without a means of livelihood.

Table 2: Demographic information of respondents

\begin{tabular}{|c|c|c|c|}
\hline Variable & Category & Frequency & Percentage \\
\hline \multirow[t]{3}{*}{ Sex } & Male & 541 & 53.6 \\
\hline & Female & 469 & 46.4 \\
\hline & Total & 1010 & 100.0 \\
\hline \multirow[t]{4}{*}{ Age } & $18-23$ years & 237 & 23.5 \\
\hline & $24-29$ years & 432 & 42.8 \\
\hline & $30-35$ years & 341 & 33.8 \\
\hline & Total & 1010 & 100.0 \\
\hline \multirow[t]{6}{*}{ Educational level } & FSLC & 208 & 20.6 \\
\hline & SSCE/GCE & 322 & 31.9 \\
\hline & NCE/OND & 264 & 26.1 \\
\hline & BD/HND & 197 & 19.5 \\
\hline & MD/PH.D & 19 & 1.9 \\
\hline & Total & 1010 & 100.0 \\
\hline \multirow[t]{4}{*}{ Employment status } & Underemployed & 179 & 17.7 \\
\hline & Petty business & 242 & 24.0 \\
\hline & Unemployed & 589 & 58.3 \\
\hline & Total & 1010 & 100.0 \\
\hline
\end{tabular}

Source: Fieldwork (2020)

Figure 3 presents the number of years the respondents have been unemployed. The survey found that $19.4 \%$ of the respondents have been unemployed for up to 3 years. Also, another $54.7 \%$ of the respondents indicated that they have been unemployed for $4-6$ years, $16.2 \%$ indicated that they have been unemployed for $7-9$ years, while
$7.5 \%$ have been unemployed for $10-12$ years. Surprisingly, $2.2 \%$ of the respondents, (consisting of 13 males and 9 females), indicated that they have been unemployed for over 13 years. This information is important for this study especially as it further reveals the extent of unemployment in the study locale.

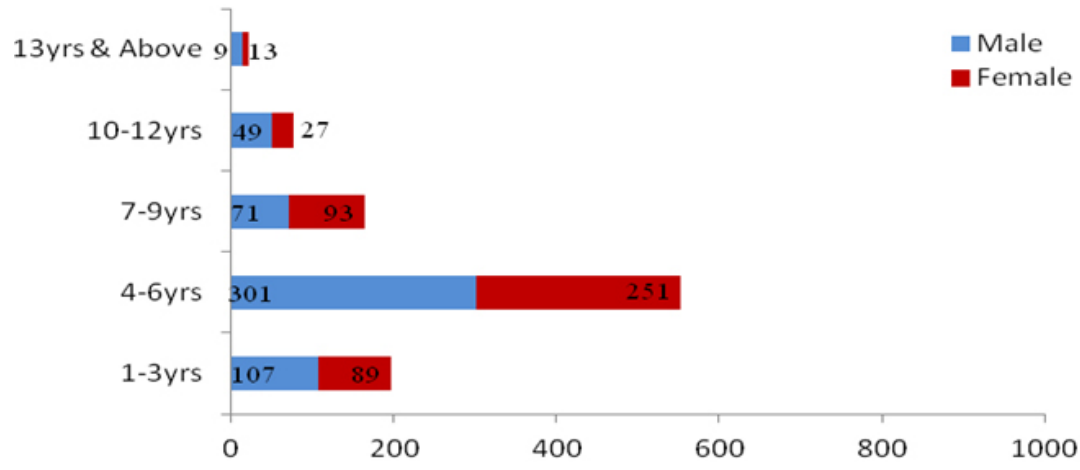

Fig. 3: Years of respondents' unemployment. Source: Fieldwork (2020) 
Causes of Poverty Among Youths in Cross Rivers State

One of the main objectives of this study is to investigate the nature and causes of poverty among unemployed youths in Cross River State, Nigeria. Table 3 represents the responses from the respondents on the factors that cause them poverty.

Table 3: Distribution of respondents on the causes of poverty

\begin{tabular}{lccc}
\hline Responses on the cause of poverty & Agree & Disagree & Total \\
\hline Limited access to credit (loan) & 896 & 114 & 1010 \\
& $(88.7 \%)$ & $(11.3 \%)$ & $(100.0 \%)$ \\
Lack of gainful employment & 918 & 92 & 1010 \\
& $(90.9 \%)$ & $(9.1 \%)$ & $(100.0 \%)$ \\
Inflation (the sudden increase in the cost of living) & 991 & 19 & 1010 \\
Poor implementation of poverty alleviation programmes & $(98.1 \%)$ & $(1.9 \%)$ & $(100.0 \%)$ \\
& $(889.0 \%)$ & $(12.0 \%)$ & $(100.0 \%)$ \\
Mass illiteracy caused by inadequate access to education & 952 & 58 & 1010 \\
Bad governance and poor leadership & $(94.3 \%)$ & $(5.7 \%)$ & $(100.0 \%)$ \\
& 908 & 102 & 1010 \\
\end{tabular}

Source: Fieldwork (2020)

As can be deduced from Table 3, an overwhelming $88.7 \%$ of the respondents agreed that limited access to credit has contributed to their poverty and to that of many other youths in the State, while only $11.3 \%$ of the respondents disagreed. It can be deduced, therefore, that limited access to credit further exacerbates the poverty among unemployed youths. This finding is supported by Ahmed, Hill, Smith, and Frankenberger ${ }^{48}$ who revealed in their study that some of the major causes of poverty in society were limited access to credit and the inability of the poor household to invest in property and education, etc. In the second row, $90.9 \%$ agreed that lack of gainful employment opportunities is one of the contributing factors to poverty among youths in the State; however, 9.1\% disagreed. By implication, the decision of the majority of the respondents lend credence to the position of Child Poverty Action Group $^{49}$ and Bursova, 50 who noted that lack of productive and paid employment is a leading cause of poverty in most countries including developed societies like the United States. In the third row, $98.1 \%$ of the respondents agreed that inflation also contributes to their poverty. In line with this finding, Cardoso ${ }^{51}$ who believed that inflation increases poverty, have argued that the problem of poverty is aggravated when the prices of commodities increase. Furthermore, with the inflation rate at $13.39 \%$ in the $1^{\text {st }}$ quarter of 2020 , it can also be seen that the increase in the price of goods, services, and sundries has worsened the misery index in Nigeria - having been ranked sixth (43.0\%) in the world. ${ }^{52,7}$

In the fourth row, $88 \%$ of the respondents agreed that poor implementation of poverty alleviation programmes in the state also contribute to their poor socio-economic conditions, implying that the failure of institutional responses to poverty like the National Poverty Eradication Programme, the Youth Empowerment Scheme (YES), among many others, has contributed to increasing poverty index in the State. On the contrary, $12 \%$ of the respondents disagreed. As shown in the fifth row, 94.3\% of the respondents agreed that mass illiteracy caused by limited access to education is also a contributing factor to poverty among unemployed youths in the State. This position is supported by Adiseshiah ${ }^{53}$ who opines that there is a close connection between illiteracy and poverty at all levels - global, national, and sub-national, and the countries with the lowest levels of literacy are also the poorest economically. 
The sixth row shows that the majority of the respondents (89.9\%) agreed that bad governance and poor leadership causes poverty in the State; this is in line with the findings of Ejere ${ }^{54}$ who argues that the worsening poverty situation in Nigeria is due to poor political leadership and the resultant bad governance; however, $10.1 \%$ of the respondents hold a contrary opinion. In sum, all the identified variables - limited access to credit, unemployment, inflation, poor implementation of institutional response to poverty, illiteracy, bad governance, and poor leadership, are perceived to be the causes of poverty among unemployed youths in the Cross river state as well as in Nigeria.

The qualitative data lends credence to the earlier identified variables as participants repeatedly expressed these factors as their personal experience and some were even emotional on the subject. One of the participants who blamed bad governance and poor leadership as the cause of poverty in the State has this to say:

You can see that nothing (socio-economic development) is happening in this country. All our leaders do is to embezzle our money for their selfish gain. For example, tell me one thing this present government has done to help the poor. You read in the newspaper and hear on the radio that billions of naira has been given to the poor but where can we find it? Ever since I completed my University programme, which was four years ago, no job! I have applied to several places and what I hear is 'who do you know'? 'What can you give'? The situation is very painful. (IDI: Youth, Female, 29, Central Senatorial District).

A participant from the Northern Senatorial District believes that unemployment is the cause of poverty in the State. The participant has this to say:

My brother, there is no job in this State, why will not the youths be poor? Where did you expect young people like us to get money to do business from? Count the number of people graduating and attending NYSC (National Youths Service Corps) every year and compare it to the number of jobs available, you will know that we are in big trouble. The worst is that the environment is not friendly to do business. If it is not government agents (tax collectors) today it will be banditry, I am fed up poverty is increasing every minute and seconds (IDI: Youth, Male, 33, Northern Senatorial District).

Another participant from the Southern Senatorial District believes that poor implementation of poverty alleviation programmes is the cause of poverty in Nigeria as they lament the failure of government programmes like family support, support for small businesses, etc. in their words:

There is no country without poor people but most developed countries, like America, manage their own properly. It is not like that in Cross River state - every government (political dispensation) comes in with different programmes to help the poor but none of the programmes is working because the government is not sincere about them. They give out funds to agents and organisers to manage these programmes but never do follow-up nor hold anyone accountable for mismanagement. That is why poverty is increasing every day without a solution (IDI: Youth, Female, 25, Southern Senatorial District).

Some participants blamed the spate of poverty in the State on the cost of living (inflation), dwindling nature of support for SMEs (small and medium enterprises) and poor investment in vocational studies. In the words of one of the participants': "No bank or firm is willing to loan you money, if at all they want to try, their requirements cannot be met by a common man and don't even think that the government is going to help you, the will rather want you as their mistress or use and dump you"(IDI:Youth, Female, 59, Southern Senatorial District).

\section{Impact of Poverty on Youth and the Society}

Data presented in Table 4 below shows that the majority of the respondents agreed that poverty is capable of affecting unemployed youths in different ways, including loss of confidence and low selfesteem $(89.2 \%)$, stress and depression due to joblessness $(88.5 \%)$, inability to access quality health services leading to a high mortality rate (91.2\%), inability to afford accommodation (87.7\%), inability to afford formal education (94.2\%) and inability to afford healthy food (93.8\%). In agreement, some scholars (Lindsey, ${ }^{55}$ Moore, et al., ${ }^{56}$ Ratcliffe \& McKernan, ${ }^{57}$ and Sanders ${ }^{58}$ ) opined that poverty 
has lifelong impacts, especially for youths. They noted that generally, poor youths are more likely to drop out of school, become homeless, suffer hunger and malnutrition, develop low self-esteem and depression, and are more likely to have an employment problem.

Table 4: Distribution of respondents on the perceived impact of poverty

\begin{tabular}{lccc}
\hline Responses on the impact of poverty & Agree & Disagree & Total \\
\hline Loss of confidence and low self-esteem & 901 & 109 & 1010 \\
& $(89.2 \%)$ & $(10.8 \%)$ & $(100.0 \%)$ \\
Stress and depression due to joblessness & 894 & 116 & 1010 \\
& $(88.5 \%)$ & $(11.5 \%)$ & $(100.0 \%)$ \\
Inability to access quality health services leading to a high mortality rate & 921 & 89 & 1010 \\
& $(91.2 \%)$ & $(8.8 \%)$ & $(100.0 \%)$ \\
Homelessness due to inability to afford accommodation & 886 & 124 & 1010 \\
& $(87.7 \%)$ & $(12.3 \%)$ & $(100.0 \%)$ \\
School dropout due to inability to afford formal education & 951 & 59 & 1010 \\
& $(94.2 \%)$ & $(5.8 \%)$ & $(100.0 \%)$ \\
Hunger and malnutrition due to inability to afford healthy food & 947 & 63 & 1010 \\
& $(93.8 \%)$ & $(6.2 \%)$ & $(100.0 \%)$ \\
\hline
\end{tabular}

Source: Fieldwork (2020)

The qualitative data lends credence to the variables highlighted. The participants of the IDI all agreed that poverty has a lot of impact on the youth in the State. For most of the participants, many youths, as a result of the hardship of poverty and unemployment, feel inadequate, hopeless, and frustrated. One of the participants identified hunger and malnutrition as the notable sign of poverty, and it is prevalent among young persons. He noted that:

Everybody knows that hunger is not good. If you don't have food to eat, you will not able to do anything. People are suffering because of hunger in Nigeria, if you go to the north (Northern region of Nigeria) for example, a lot of youths and children are roaming the street begging for food. The worst is in IDP Camps, you will see a visible sign of hunger and malnutrition everywhere. The people are under-fed and they cannot do anything because they are poor and helpless. (IDI: Youth,

Male, 29, Southern Senatorial District).

Another participant from the central senatorial district identified high mortality rates as the negative effect of poverty. The participant has this to say:
Poverty and good health cannot go together. The poor are likely to die ten times more than the rich. Let us not forget that money is involved, if you do not have money how do you treat yourself? I recall when i was very ill, no hospital or clinic is ready to attend to you without money even our primary health centres are so concerned about money that people now refer to them as death traps. Poverty

is a disease that no one wants to associate with. (IDI: Youth, Female, 32, Central Senatorial District).

A participant from Northern Senatorial District believed that the most visible symptoms of poverty are manifested in the inability to afford accommodation especially for city or urban dwellers. To put in their words:

Most people residing in a city migrate to those places for better opportunities and they must find a place to stay, and that takes a lot of money. If you visit places like Lagos, Abuja, Kano some people are living under the bridges because they cannot afford accommodation. In some places in Calabar, a lot of my friends are homelessness 
because they cannot afford the outrageous house rent in the city. (IDI: Youth, Male, 32, Northern

Senatorial District).

Some other participants narrated how poverty and economic hardship caused them poor academic performance and behavioural or socio-emotional problems. One of the respondents explained that: "Poverty reduces your chances to excel. In my Secondary school days, I could hardly feed or afford clothes and other school requirements; as a result, I performed poorly academically. Worst still, some of us could not pay school fees, especially those who are self-sponsored, and most of us dropped out of school or go into criminal life just to survive". (IDI: Youth, Male, 25, Central Senatorial District).

\section{Coping Strategies}

The third objective of this study is to examine the coping strategies of poor and unemployed youths, and how youths in Cross River State respond to the negative outcomes of poverty. Whereas the respondents of this study indicated that they and some other youths in their communities engage in petty trading, scavenging (picking and selling metals, plastics, and recyclable materials), casual jobs (as factory workers, store managers, receptionists, hotel porters, etc), transport jobs (as drivers or conductors), ushering jobs, street hawking and street begging to cope with their unemployment and poverty, they also agreed that many youths in the
State engage in negative and detrimental activities to cope with poverty and unemployment.

The responses in Table 5 above imply that the majority of the respondents agreed that poverty provides a conduit for the manifestation of different maladaptive behaviours as a coping strategy by unemployed youths in the State. In other words, the majority of the respondents agreed that some unemployed youths respond negatively to poverty and unemployment by engaging in commercial sex work and other illicit sex behaviour (87.1\%), armed robbery and kidnapping $(91.8 \%)$, betting and gambling $(87.0 \%)$, drugs and other substances abuse (93.2\%), theft and cyber fraud $(89.0 \%)$ and violence and other aggressive behaviours (88.3\%). With those who disagreed in the minority, it means, all the variables listed as the youths' coping response to poverty are valid. This is in synch with Wadsworth and Berger59 argument that youths who grow up in environments of poverty find fewer opportunities for social, personal, and educational development - they are more likely to become perpetrators or victims of street violence, to experience greater residential instability, drug abuse, domestic violence, fewer educational opportunities and they are permanently exposed to negative life models (criminal tendencies). Today, internet fraud, popularly called 'yahoo-yahoo', has become prevalent among youths, with many young people joining daily the business of online romance scams, phishing, networking and Ponzi scheme scams, job

Table 5: Perceived coping strategies or youths' response to poverty

\begin{tabular}{lccc}
\hline Responses on the coping strategies & Agree & Disagree & Total \\
\hline Commercial sex work and other illicit sex behavior & 880 & 130 & 1010 \\
Armed robbery and kidnapping & $(87.1 \%)$ & $(12.9 \%)$ & $(100.0 \%)$ \\
& 927 & 83 & 1010 \\
Betting and Gambling & $(91.8 \%)$ & $(8.2 \%)$ & $(100.0 \%)$ \\
& 879 & 131 & 1010 \\
Drugs and other substances abuse & $(87.0 \%)$ & $(13.0 \%)$ & $(100.0 \%)$ \\
& 941 & 69 & 1010 \\
Theft and cyber fraud & $(93.2 \%)$ & $(6.8 \%)$ & $(100.0 \%)$ \\
& 899 & 111 & 1010 \\
Violence and other aggressive behaviours & $(89.0 \%)$ & $(11.0 \%)$ & $(100.0 \%)$ \\
& $(89.3 \%)$ & $(11.7 \%)$ & $(100.0 \%)$ \\
\hline
\end{tabular}

Source: Fieldwork (2020) 
employment scams, and charity scams targeted at donor agencies, organizations, and philanthropists.

Date from the interviews further supported the quantitative data above, revealing that unemployed youths in the State respond to poverty in different negative ways, including commercial sex work. One of the participants explained that:

The youths cannot afford to be idle, poor and frustrated. You know the popular saying "use what you have to get what you want". The easiest job to do especially for a female is prostitution, which is increasing day by day as poverty bites harder in the country. After 4 years of unemployment and many failed petty businesses, I have been coping by doing small-small runs (sex work). There are also some of my friends that are into yahoo-yahoo, corporate begging and many other demeaning menial jobs. They must do these things to keep body and soul going. It may interest you to know that when these people get something to do (job)

only very few will go back to the streets. (IDI: Youth, Female, 26, Northern Senatorial District).

Some other participants explained that many youths in the State respond to poverty by engaging in betting and gambling. An interviewee in Southern Senatorial District noted that:

Look around, you will find many betting and gambling shops. The streets in the cities are busy day and night with young men and women gambling at betting shops. Women too are not left out, even primary school children. Me I do it too, you don't know if that is how heaven will smile on me (IDI: Youth, Male, 35, Southern Senatorial District).

Some participants also explained that Nigeria's depreciating reputation in the international community is a direct response to the increasing poverty index in the country. They hint that most crimes especially cyber fraud, theft, armed robbery, kidnapping, and other financial related offenses are proceeds of poverty. One participant said:

The increasing crime rates in Nigeria can only be traced to poverty. Nigeria is a laughing stock in the international community because of the activities of our boys on the internet. The EFCC (Anti-Graft body) is going after them but the situation has not changed. The country must find a way to engage the youths because they desire to live a comfortable life and when that is not coming, your guess is as good as mine. In every criminal activity like armed robbery, kidnapping, or fraud the youths take the lead. The government has to engage the youths meaningfully to dissuade them from criminal activities. (IDI: Youth, Female, 27, Central Senatorial District).

Other participants were able to identify drug and substance abuse as the coping response to poverty among youths in Cross River State. A youth from the central senatorial district discussed extensively on the subject by saying: "I can tell you from experience since I left school after graduation, there is nothing I have not done to keep myself busy job-wise, but it appears as if there is a force of darkness after me. Nothing is working for me. Initially, I do not smoke but after my shop got burnt hardly can you see me without this 'Igbo' (marijuana). I nearly committed suicide and my friends who came to rescue me said if I take this thing, I would forget my sorrow. So, each time I think about it I have to smoke something to take my mind away. Many guys in this community that have nothing to do come here every morning and evening to console themselves by taking all these substances as a distraction from the reality of life". (IDI: Youth, Male, 34, Central Senatorial District).

\section{Summary and Conclusion}

Whereas poverty is a common social fact existing in virtually every society, the concern of social scientists is the social consequences of poverty and how socio-economically disadvantaged persons cope with poverty. As revealed in this study, youth poverty is one of the increasing socio-economic challenges in Cross River State and can be traced to several factors, including structural and personal factors such as limited access to loans, inflation rates, poor implementation of state policies, bad governance, mass illiteracy, negative cultural values, low aspirations, and the lack of employment opportunities for the teeming youth population. It is also noted here that the socio-economic consequences of this increasing phenomenon of poverty are enormous and results in many social problems affecting sustainable development. 
As found in this study, many youths in Cross River State, owing to poverty, suffer indescribable hardship and experience loss of confidence and self-esteem, increased stress and frustration, homelessness, hunger, starvation, and inability to access quality social services, including education and healthcare. Beyond these, many of the respondents indicated that poverty and unemployment have denied them the productive periods of their lives, and as a result, they feel hopeless, ineffective, and frustrated. Unfortunately, this sad reality is largely applicable to youths in other parts of the country.

It is important to note here that the phenomenon of poverty and unemployment has also been connected to the aggravation of criminality, youth restiveness, and disorder in Cross River State and the country as a whole. As noted by Bursova, ${ }^{50}$ Inyang, Arikpo, and Ndiyo, ${ }^{14}$ and Ingwe, ${ }^{12}$ poverty and unemployment among youths contribute to the rapid growth of criminal gangs, militants, and hoodlums terrorizing the Nigerian State today. Many youths are also available for employment as hoodlums and thugs for election violence, civil disturbance, and protests mainly because they are impoverished, frustrated, and desperate. This is aside from the growing number of youths who indulge in gambling, yahoo-yahoo (internet fraud), kidnapping, and theft, as a way to escape poverty or punish the system for their destitution. Participants of this study equally affirmed that some of the ways youths in Cross River State cope with poverty include indulging in commercial sex work and other illicit sexual behaviour, armed robbery, kidnapping, street begging, drug trafficking and other substance abuse, cyber fraud, and theft. The deteriorating job outlook in the country also provides little solace for youths who are not given to violence, criminality, and aggressive behaviour. Consequentially, these restricted opportunities further exert strain on the youth population and driving more of them into a negative coping mechanism.

\section{Recommendations}

In response to the findings of this study and the glaring consequences of poverty on unemployed youths in the State, the following are recommended for policy development and as specific solutions:

- The State, at all levels, should create programmes and funding for skills development, vocational training, and youth capacity building in all parts of the State. For a wholesome and positive outcome, such programmes should be accessible to all irrespective of age, gender, locality, political affiliation, or social status.

- $\quad$ Furthermore, credit facilities and free-business support should be available for young persons who wish to engage in small and medium scale businesses in and outside the State.

- Good and effective governance is also an important factor for youth development and sustainable development, particularly as it has implications for equitable distribution of resources, job creation, inflation rates, business environment, property rights, interest rates, and income. Thus, the State, at all levels, must ensure stable political governance by eliminating corruption and misappropriation of funds, ethnic politics, and improbity in governance, while encouraging, effectiveness, rule of law, accountability, and fairness among public institutions.

\section{Funding}

The author(s) received no financial support for the research, authorship, and/or publication of this article.

\section{Conflict of Interest}

The authors do not have any conflict of interest.

\section{References}

1. Müller-Jung, F (2018, October 17). World Bank report: Poverty rates remain high in Africa. Accessed 17 $17^{\text {th }}$ May 2019 from https://www. dw.com/cda/en/world-bank-report-poverty- rates-remain-high-in-africa/a-45926382

2. The Globalist (2017, June 18). By the Numbers: Poverty in Africa. Accessed 14 ${ }^{\text {th }}$ May 2019 from https://www.theglobalist.com/by-the-numbers- 
poverty-in-africa/

3. Kazeem, Y (2018, June 25). Nigeria has become the poverty capital of the world. Accessed 25 th June 2019 from https://qz.com/africa/1313380/ nigerias-has-the-highest-rate-of-extremepoverty-globally/

4. Akanle, O \& Adésìnà, J.O (2017). The Development of Africa: Issues, Diagnoses, and Prognoses. DOI: 10.1007/978-3-319-66242-8. Publisher: Springer. ISBN: 978-3-319-66241-1

5. Anyanwu, J.C \& Anyanwu, J.C (2017). "The Key Drivers of Poverty in Sub-Saharan Africa and what can be done about it to achieve the poverty Sustainable Development Goal," Asian Journal of Economic Modelling, Asian Economic and Social Society, Vol. 5(3), pages 297-317, September.44

6. Shepherd, A, Mitchell, T, Lewis, K, Lenhardt, A, Jones, L, Scott, L \& Muir-Wood, R (2013). "The geography of poverty, disasters and climate extremes in 2030". London: Overseas Development Institute

7. National Bureau of Statistics (2019). Labour Force Statistics - Volume 2: Unemployment and Underemployment by State, pages 11126. Accessed 23 $3^{\text {rd }}$ May 2020 from https:// nigerianstat.gov.ng/download/929

8. Premium times (2020, May 2). Nigeria's unemployment rate hits 33.5 percent by 2020 - Minister. Accessed 15 $15^{\text {th }}$ May 2020 from https://www.premiumtimesng.com/news/topnews/328137-nigerias-unemployment-rate-hits33-5-per-cent-by-2020-minister.html

9. Olawoyin, O. (2018, December 19) Nigeria's unemployment rate rises to $23.1 \%$ - NBS. Accessed $12^{\text {th }}$ January 2019 from https://www. premiumtimesng.com/news/headlines/301896nigerias-unemployment-rate-rises-to-23-1-nbs. $\mathrm{htm}$

10. Statista Research Department (2020, June 2). Unemployment rate in Nigeria in 2018 , by states. Accessed 7 th June 2020 by 2.32 am from https://www.statista.com/statistics/1119533/ unemployment-rate-in-nigeria-by-state/

11. World Population Review (2020, July 1) Nigeria Population 2020 (Live). Accessed 3:45 pm on Sunday, $23^{\text {rd }}$ August 2020 from https://worldpopulationreview.com/countries/ nigeria-population\#: :text=Nigeria $\% 27 \mathrm{~s} \% 20$ population $\% 20$ is $\% 20$ predicted $\% 20$ to $\% 20$ hit\%20206\%

12. 20 million,crossing $\% 20$ the $\% 20300 \% 20$ million\%20threshold\%20around\%202036.\%20 $00 \% 3 \mathrm{~A} 01$

13. Ingwe, R. (2009). Persisting poverty, unemployment/underemployment in Cross River State, Nigeria: The urgency of improving good governance and participation in the State Economic Empowerment and Development Strategy. International NGO Journal. 4. 34-45.

14. Essia, U. \& Yusuf, A. (2013). Active Poor" Phenomenon and Youth Unemployment in Cross River State, Nigeria - Some Diagnosis. International Journal of Financial Research, Vol. 4(4), http://dx.doi.org/10.5430/ijfr.v4n4p118

15. Inyang, E., Arikpo, D. \& Ndiyo, N. (2015). Unemployment and Poverty in Nigeria. Multi-Disciplinary Journal of Research and Development Perspectives. Volume 4, Number 1, June 2015

16. Okpa, J.T. (2019). Unemployment and Drug Trafficking Among Suspects in Custody of the National Drug Law Enforcement Agency, Cross River State Command, Nigeria". European Scientific Journal. DOI: 10.19044/esj.2019. v15n19p191

17. Organization for Economic Co-operation and Development (2019). Employment rate by age group (indicator). DOI: 10.1787/084f32c7-en. Accessed 21st December 2019 from www. data. oecd.org/employment-rate-by-age-group.htm

18. Fajana, S (2000). Functioning of the Nigerian Labour Market. Lagos: Labonfin and Company. ISBN: 97834843549789783484351

19. International Labour Organization, ILO (2016) Unemployment and non-standard employment around the world: Understanding challenges and shaping prospects. www.ilo.org/wcmsp5/ groups/public/---dgreports/---dcomm/---publ/ documents/publication/wcms_534497.pdf

20. The Sun (2017, February 6). Nigeria's rising misery index. Accessed $4.35 \mathrm{pm}$ on the $24^{\text {th }}$ of June, 2019 from Sun Newspaper https://www. sunnewsonline.com/nigerias-rising-miseryindex-ranking/

21. World Summit for Social Development (1995) Economic and Social Development at the United Nations. Accessed $24^{\text {th }}$ may, 2015 from https:// www.un.org/esa/socdev/wssd/text-version/ index.html 
NWAKANMA \& IGBE, Current Research Journal of Social Sciences, Vol. 03(2) 262-279 (2020) 278

22. Center for Economic and Social Rights (2009). Poverty and Human Rights: is poverty a violation of human rights? Accessed $23^{\text {rd }}$ June 2017 from https://www.cesr.org/poverty-and-humanrights-poverty-violation-human-rights

23. Oxfam International (2020). Supporting today's youth, the best chance to end poverty tomorrow. Accessed $5^{\text {th }}$ May 2020 from https://www.oxfam. org/en/supporting-todays-youth-best-chanceend-poverty-tomorrow

24. Moore, K. (2005). Thinking about youth poverty through the lenses of chronic poverty, life-course poverty, and intergenerational poverty. Chronic Poverty Research Centre. A working paper for the Institute for Development Policy and Management (IDPM), School of Environment and Development, University of Manchester, United Kingdom. ISBN: 1-904049-56-7

25. Curtain, R. (2004). Youth in extreme poverty: dimensions and country responses. In the United Nations, World Youth Report 2003 - The global situation of young people, New York: UN.

26. Gleeson, P (2019). The Overall Effects of Unemployment. Accessed online on the 24th August 2019 from https://smallbusiness.chron. com/overall-effects-unemployment-37104.html

27. Martinez, R.., Ayala, L., \& Ruiz-Huerta, J. (2001). The impact of unemployment on inequality and poverty in OECD countries. The Economics of Transition, 9(2), 417-447. doi:10.1111/1468-0351.00082

28. Kellog, N.C (2018, May 28) Top effects of poverty. Accessed $12^{\text {th }}$ July 2019 from https:// borgenproject.org/5-effects-poverty/

29. Narayan, D \& Petesch, P (2007). Moving out of Poverty. New York: World Bank and Palgrave MacMillan

30. Akire, A (2002). Dimensions of Human Development. Journal of World Development. 30 (2), pp 181-205. Accessed online on the 29th February 2019 at 3.58 pm from http:// www.sciencedirect.com/science/article/pii/ S0305750X01001097

31. Alsan, M.M, Westerhaus, M., Herce, M., Nakashima, K. \& Farmer, P.E (2011). Poverty, Global Health, and Infectious Disease: Lessons from Haiti and Rwanda, Infectious Disease Clinics of North America, Vol 25 (3), Pages 611622. ISSN: 0891-5520, https://doi.org/10.1016/j. idc.2011.05.004.
32. Singh A.R. \& Singh, S.A. (2008). "Diseases of Poverty and Lifestyle, Well-Being and Human Development". Mens Sana Monographs. 6 (1): 187-225. doi:10.4103/0973-1229.40567. PMC 3190550. PMID 22013359.

33. Goldsmith, A.H., Veum, J.R., \& Darity, Jr., W. (1997). Unemployment, joblessness, psychological well-being, and selfesteem: Theory and evidence. Journal of SocioEconomics, 26(2), 133-158.

34. Psychologenie (2019). How Unemployment Affects Mental and Physical Health. Accessed 27th May 2019 from https://psychologenie.com/ how-unemployment-affects-mental-physicalhealth

35. Heflin, C.M. \& Iceland, J. (2009). "Poverty, Material Hardship and Depression". Social Science Quarterly. 90 (5): 1051-1071.

36. Chakravarti, D. (2006). "Voices Unheard: The Psychology of Consumption in Poverty and Development", Journal of Consumer Psychology, 16 (4): 363-376, doi:10.1207/ s15327663jcp1604_8

37. Grondona, M. (2000). "A cultural Typology of Economic Development", in Harrison, Lawrence E.; Huntington, Samuel P. (eds.), Culture Matters, New York, NY: Basic Books, pp. 44-55.

38. Newman, K.S. (1999). Falling From Grace. Berkeley and Los Angeles, CA: University of California Press.

39. Lewis, O. (1998). "The culture of poverty". Society. 35 (2): 7-9. doi:10.1007/BF02838122. Accessed $2.30 \mathrm{pm}$ on the $24^{\text {th }}$ of May, 2017 from Springer books https://link.springer.com/ article/10.1007/BF02838122\#citeas

40. Schiller, B. (1972). The Economics of Poverty and Discrimination. $1^{\text {st }}$ ed. New Jersey: PrenticeHalle

41. Crossman, A (2018, July 22) Definition of Opportunity Structure. Accessed $21^{\text {st }}$ May 2019 from https://www.thoughtco.com/opportunitystructure-theory-3026435

42. Pineda, M.E. (2018, September 19). Theories of Poverty. Accessed 23 $3^{\text {rd }}$ June 2019 from https:// www.profolus.com/topics/theories-of-poverty/

43. Cloward, R.A \& Ohlin, L.E (1960) Delinquency and Opportunity, a Theory of Delinquent Gangs. Glencoe, III. The Free Press

44. Jang, S.J. \& Agnew, R. (2015). Strain Theories and Crime. In: J.D. Wright (ed), International 
Encyclopaedia of the Social \& Behavioural Sciences, $2^{\text {nd }}$ edition, Vol 23. Oxford: Elsevier. pp. 495-500. ISBN: 9780080970868

45. Macionis, J.J. \& Gerber, L.M., (2009). Sociology. Pearson prentice hall publishers. New Jersey: Upper Saddle River

46. Agnew, R., (1992). Foundation for a general strain theory of crime and delinquency. Criminology 30 (1), 47-88.

47. Independent National Electoral Commission (2015), 2015 Elections. Accessed $14^{\text {th }}$ May 2018 from https://www.inecnigeria.org/elections/ polling-units/

48. Nigerian National Youth Policy (2009). Nigeria Youth policy. Accessed 23 $3^{\text {rd }}$ May 2017 from https://www.youthpolicy.org/factsheets/country/ nigeria/

49. Ahmed, A.U., Hill, R.V., Smith L.C. \& Frankenberger, T. (2007, October). Characteristics and causes of severe poverty and hunger. International Food Policy Research Institute. Retrieved on $15^{\text {th }}$ July 2015.

50. Child Poverty Action Group (2015). What causes poverty? Retrieved 14 July 2015 from www. cpag.org.uk

51. Bursova, J. (2019). Poverty caused by unemployment, its consequences, and solutions. Warszawa: Szkola Wyzsza im. Bogdana Janskiego UI.

52. Cardoso, E. (1992, March). Inflation and poverty. NBER Working Paper. No.w4006.

53. Hanke, S.H (2019, March 28) Hanke's Annual
Misery Index 2018: The World's Saddest (and Happiest) Countries. Accessed 23 $3^{\text {rd }}$ June 2019 at $5.15 \mathrm{pm}$ from https://www.forbes.com/sites/ stevehanke/2019/03/28/hankes-annual-miseryindex-2018-the-worlds-saddest-and-happiestcountries/?sh=59ab845d3bce

54. Adiseshiah, M.S. (1990). Illiteracy and poverty - Literacy lesson. International Bureau of Education, Geneva, Switzerland.

55. Ejere, E.S. (2013). Leadership, governance, and poverty in Nigeria. Research in Humanity and Social Sciences, Vol 3(7)

56. Lindsey, D. (2009). Child poverty and inequality: Securing a better future for America's children. New York: Oxford University Press

57. Moore, K.A., Redd, Z., Burkhauser, M., Mbawa, K. \& Collins, A. (2009). Children in poverty: Trends, consequences, and policy options. Washington: Child Trends.

58. Ratcliffe, C. \& McKernan, S.M. (2010). Childhood poverty persistence: Facts and consequences. Washington: Urban Institute Press.

59. Sanders, L. (2011). Neuroscience exposes pernicious effects of poverty. Science News, 179(3)

60. Wadsworth, M.E. \& Berger, L.E. (2006). Adolescents coping with poverty-related family stress: Perspective predictors of coping and psychological symptoms. Journal of Youth and Adolescence, 35(1), 57-70. https://doi. org/10.1007/s10964-005-90225. 